\title{
KAJIAN INTERTEKSTUALITAS DALAM NOVEL SITI NURBAYA KARYA MARAH RUSLI DAN LAILA MAJNUN KARYA SYAIKH NIZAMI
}

\author{
Pipik Asteka
}
Pendidikan Bahasa dan Sastra Indonesia Universitas Majalengka

e-mail: pipikasteka86@gmail.com

\begin{abstract}
ABSTRAK
Dua karya sastra atau lebih yang mengangkat tema yang sama terdapat persamaan dan perbedaan. Persamaan dan perbedaan tersebut menandakan bahwa setiap pengarang mempunyai pesan tersendiri yang disampaikan melalui karyanya. Persamaan dan perbedaan dalam beberapa karya sastra dapat dianalisis dengan menggunakan prinsip intertekstualitas. Prinsip ini dimaksudkan untuk mengkaji teks yang dianggap memiliki hubungan tertentu dengan teks lain sehingga dimungkinkan suatu karya menjadi hipogram bagi karya sastra selanjutnya. Tujuan penelitian ini adalah pendeskripsian kajian intertekstualitas pada Novel Siti Nurbaya Karya Marah Rusli dengan Novel Lalla Majnun Karya Syaikh Nizami.

Penelitian novel "Siti Nurbaya karya Marah Rusli dan Laila Majnun Karya Syaikh Nizami" menggunakan metode kualitatif, yaitu penelitian yang bersifat deskriptif. Penelitian kualitatif merupakan penelitian yang cenderung menggunakan analisis. Pendekatan penelitian ini menggunakan kajian intertekstualitas yaitu membandingkan dua buah teks yang diduga memiliki keterkaitan dan pendekatan intertekstual ini untuk menemukan hipogram dan transformasi dalam novel Siti Nurbaya dan Laila Majnun.

Kedua cerita Novel Lalla Majnun karya Syaikh Nizami dan Novel Siti Nurbaya Cinta karya Marah Rusli di atas yakni memiliki unsur tema yang hampir sama yaitu tentang perjuangan cinta sejati sepasang kekasih yang mengalami cobaan atau hambatan namun menyatu dalam sebuah keabadian mengunakan sudut pandang yang sama yakni sudut pandang orang ketiga dan lain-lain. Selain persamaan ada juga perbedaan yakni terletak pada struktur gaya bahasa, latar sosial dan lain-lain.

Novel Siti Nurbaya karya Marah Rusli merupakan hipogram untuk novel Laila Majnun karya Syaikh Nizam. Hal itu terbukti karena adanya persamaan ide dan peristiwaperistiwa yamg terjadi dalam novel Laila Majnun yang sudah lebih dulu diekspresikan Marah Rusli dalam novelnya yang berjudul Siti Nurbaya, kemudian di transformasikan oleh Syaikh Nizam pada novelnya yang berjudul Laila Majnun.
\end{abstract}

\section{Kata Kunci: Siti Nurbaya, Laila Majnun, Intertekstualitas, Hipogram.}

\section{PENDAHULUAN}

Karya sastra sebagai cerminan kehidupan masyarakat, merupakan dunia subjektivitas yang diciptakan oleh pengarang yang di dalamnya terdapat berbagai aspek kehidupan yang saling berkaitan satu dengan yang lainnya. Aspek kehidupan tersebut berupa aspek sosiolologis, psikologis, filsafat, budaya, dan agama. Keberadaan karya sastra tidak dapat dilepaskan dari diri pengarang sebagai bagian dari anggota suatu masyarakat. Sehingga dalam penciptaannya, pengarang tidak dapat terlepas dari lingkungan sosial budaya yang melatarinya.

Dua karya sastra atau lebih yang mengangkat tema yang sama terdapat 
persamaan dan perbedaan. Persamaan dan perbedaan tersebut menandakan bahwa setiap pengarang mempunyai pesan tersendiri yang disampaikan melalui karyanya. Persamaan dan perbedaan dalam beberapa karya sastra dapat dianalisis dengan menggunakan prinsip intertekstualitas. Prinsip ini dimaksudkan untuk mengkaji teks yang dianggap memiliki hubungan tertentu dengan teks lain sehingga dimungkinkan suatu karya menjadi hipogram bagi karya sastra selanjutnya. Sejalan dengan pendapat Rina Ratih (dalam Jabrohim dan Ari Wulandari, 2001: 125) bahwa suatu teks itu penuh makna bukan hanya karena mempunyai struktur tertentu, suatu kerangka yang menentukan dan mendukung bentuk, tetapi juga karena teks itu berhubungan dengan teks lain.

Berdasarkan pernyataan di atas, beberapa karya sastra yang memiliki persamaan dan perbedaan diteliti untuk memperoleh kejelasan mengenai latar penciptaan karya sastra tersebut. Sebuah teks lahir dari teks lain sebagai sumber penciptaan karya sastra (novel). Untuk mengetahui hubungan intertekstualitas antara karya yang satu dan karya yang lainnya, tentu juga diperlukan metode perbandingan yang dapat dipertanggungjawabkan secara ilmiah. Metode perbandingan ini, yaitu dengan membandingkan unsur-unsur struktur secara menyeluruh yang terdapat di dalam beberapa karya sastra tersebut. Sebagaimana diungkapkan Riffaterre bahwa intertekstualitas memerlukan suatu metode perbandingan dengan membandingkan unsur-unsur struktur secara menyeluruh terhadap teks-teks sastra yang diteliti. Adapun teknik membandingkannya adalah dengan menjajarkan unsur-unsur struktur secara menyeluruh yang terdapat dalam karya-karya sastra yang diperbandingkan (Sangidu, 2004: 26).

Berdasarkan hal yang demikian, tujuan penelitian ini adalah pendeskripsian kajian intertekstualitas pada Novel Siti Nurbaya Karya Marah Rusli dengan Novel LaIla Majnun Karya Syaikh Nizami.

\section{KAJIAN TEORI Hakikat Intertekstualitas}

Prinsip intertekstualitas berasal dari Perancis dan bersumber pada aliran strukturalisme Perancis yang dipengaruhi oleh pemikiran filsuf Perancis, Jaquea Derrida dan dikembangkan oleh Kristeva (Rina Ratih dalam Jabrohim dan Ari Wulandari, 2001: 126). Lebih lanjut, Kristeva (dalam Jabrohim dan Ari Wulandari, 2001: 113) mendefinisikan intertekstual sebagai ringkasan pengetahuan yang memungkinkan teks mempunyai arti. Sekali kita berpendapat tentang teks seperti bergantung pada teks lain yang diserap, ditransformasi maka di situ pula intersubjektif terpasang, yaitu intertekstualitas.

Karya sastra tidak lahir dari situasi kekosongan budaya. Oleh karena itu, karya sastra tidak dapat terlepas dari konteks sejarah dan sosial masyarakat. Seperti yang dikemukakan Luxemburg (dalam Burhan Nurgiyantoro, 2005: 50) bahwa intertekstualitas diartikan sebagai kita menulis dan membaca dalam suatu 'interteks' suatu tradisi budaya, sosial, dan sastra, yang tertuang dalam teks-teks. Setiap teks sebagian bertumpu pada konvensi sastra dan bahasa dan dipengaruhi oleh teks-teks sebelumnya. Kajian intertekstual berangkat dari asumsi bahwa "kapan" pun karya ditulis, ia tidak mungkin lahir dari situasi kekosongan budaya. Unsur budaya, termasuk semua konvensi dan tradisi di masyarakat, dalam wujudnya yang khusus berupa teksteks kesastraan yang ditulis sebelumnya.

Intertekstualitas merupakan suatu analisis struktural pada teks-teks dalam hubungannya dengan sistem yang lebih besar. Sejalan dengan pendapat Landow (1992), Intertekstualitas, sebagai suatu analisis structural pada teks-teks dalam hubunganya dengan sistem yang lebih besar dari praktikpenandaan atau penggunaan tanda-tanda dalam kebudayaan, pergeseranpergeseran perhatian dari tritunggal yang diberikan oleh penutur/karya/tradisi untuk diberikan pada 
yang lain oleh teks/wacana/budaya. Juga dalam tindakan, intertekstualitas meletakkan kembali model evolusioner pada sejarah sastra dengan sebuah struktur atau model sinkronis dari kesastraan sebagai sebuah sistem tanda.Setiap teks sastra dibaca dan harus dengan latar belakang teks-teks lain. Kristeva berpendapat bahwa tidak ada sebuah teks pun yang sungguh mandiri, dalam arti bahwa penciptaan dan pembacaannya tidak dapat dilakukan tanpa adanya teks-teks lain sebagai contoh, teladan, kerangka. Tidak dalam arti bahwa teks baru hanya meneladani teks lain atau mematuhi kerangka yang telah diberikan terlebih dulu, tetapi dalam arti bahwa dalam penyimpangan dan transformasi pun model teks yang sudah ada memainkan peran penting. Pemberontakan atau penyimpangan mengandaikan adanya sesuatu yang dapat diberontaki ataupun disimpangi dan pemahaman teks baru memerlukan latar pengetahuan tentang teks-teks yang mendahuluinya (Jabrohim dan Ari Wulandari, 2001: 126; Teeuw, 1988: 145146). Lebih lanjut dikatakan Kristeva (dalam Teeuw, 1988: 146) bahwa sebuah karya dapat dibaca dalam kaitan ataupun pertentangan dengan teks-teks lain, yang merupakan semacam kisi. Lewat kisi itu, teks dibaca dan diberi struktur dengan menimbulkan harapan yang memungkinkan pembaca untuk memetik ciri-ciri menonjol dan memberikannya sebuah struktur. Sebuah karya sastra baru bermakna penuh dalam hubungannya dengan karya sastra yang lain. Riffaterre (dalam Sangidu, 2004: 24) mengemukakan bahwa karya sastra yang melatarbelakangi penciptaan karya sastra sesudahnya disebut sebagai karya hipogram. Hipogram merupakan karya yang menjadi dasar penciptaan karya lain yang lahir kemudian. Karya yang diciptakan berdasarkan hipogram itu disebut sebagai karya transformasi karena mentransformasikan teksteks yang menjadi hipogramnya. Lebih lanjut diungkapkan Riffaterre (dalam Rachmat Djoko Pradopo, 2002: 55) bahwa karya sastra yang menjadi hipogram diserap dan ditransformasikan dalam teks sastra sesudahnya yang menunjukkan adanya persamaan. Dengan menjajarkan sebuah teks dengan teks yang menjadi hipogramnya, makna teks tersebut menjadi jelas baik teks itu mengikuti maupun menentang hipogramnya. Begitu juga situasi yang dilukiskan, menjadi lebih terang hingga dapat diberikan makna sepenuhnya.

Pendapat lain yang senada dengan pendapat di atas, dikemukakan oleh Rachmat Djoko Pradopo (1997: 228) bahwa prinsip dasar intertekstualitas adalah karya hanya dapat dipahami maknanya secara utuh dalam kaitannya dengan teks lain yang menjadi hipogram. Lebih lanjut dikatakan bahwa prinsip intertekstualitas yang penting adalah prinsip pemahaman dan pemberian makna teks sendiri, tidak mempersoalkan saduran atau turunan, tetapi setiap teks itu merupakan peresapan, penyerapan, dan transformasi teks lain. Oleh karena itu, berlaku prinsip bahwa untuk dapat memberikan makna penuh sebuah teks, teks harus dibicarakan dalam kaitannya dengan teks yang menjadi hipogramnya.

Ada di bagian lain, dinyatakan bahwa untuk mendapatkan makna yang sepenuhnya itu dalam menganalisis tidak boleh dilepaskan karya sastra dari konteks sejarah dan konteks sosial-budayanya, dalam hubungan pembicaraan intertekstual ini berkenaan dengan konteks sejarah sastranya. Lebih lanjut dikemukakan bahwa sebuah karya sastra baik itu puisi maupun prosa mempunyai hubungan sejarah antara karya sezaman, yang mendahuluinya atau yang kemudian. Hubungan sejarah ini baik berupa persamaan maupun pertentangan.

Dengan demikian, membicarakan karya sastra itu sebaiknya dalam hubungannya dengan karya sezaman, sebelum, atau sesudahnya (Rachmat Djoko Pradopo, 1995: 167). Intertekstualitas erat hubungannya dengan model-model kultural. Teks dapat dipahami karena adanya modelmodel kultural yang ada sebelumnya sebagai sumber arti dan keutuhan. Hal ini disebut 
dengan vraisembable. Todorov memberikan definisi vraisembable sebagai: (1) hubungan teks tertentu dengan teks pada umumnya yang disebut dengan public union; (2) tradisi atau genre tertentu yang diharapkan; (3) penghalangan bagi suatu teks untuk berdiri sendiri karena diduga mempunyai hubungan dengan realitas. Vraisembable merupakan konsep yang mendasari intertekstualitas (Bani Sudardi, 1992: 92). Lebih lanjut dikemukakan bahwa dalam rangka membawa teks berhubungan dan berbatasan dengan teks lain, menurut Culler vraisembable dapat dibedakan menjadi 5 tingkat yang membantu teks dapat dipahami. Kelima tingkat tersebut ialah sebagai berikut.

1. Teks yang diberikan secara sosial (wujudnya dunia nyata);

2. Teks kurtural secara umum (berupa prinsip-prinsip kurtural yang ada di masyarakat; misalnya tata cara);

3. Teks atau konvensi suatu genre kesusastraan atau hal-hal lain yang sifatnya tiruan;

4. Sikap terhadap hal-hal tiruan (teks secara eksplisit menyatakan sikapnya terhadap vraisembable jenis ke-3 di atas dalam memperkuat otoritasnya);

5. Vraisembable yang rumit dari intertekstualitas yang khas dikarenakan suatu karya menempatkan karya lain sebagai tempat berangkat dan harus dipahami dalam hubungannya dengan teks tersebut.

Secara garis besar, penelitian intertekstualitas memiliki dua fokus. Pertama, meminta perhatian kita tentang pentingnya teks yang terdahulu (prior texs). Tuntutan adanya otonomi teks sebenarnya dapat menyesatkan gagasan, sebuah karya memiliki arti karena dalam hal-hal tertentu telah dituliskan lebih dahulu oleh pengarang lain. Kedua, intertekstualitas akan membimbing peneliti untuk mempertimbangkan teks terdahulu sebagai kode yang memungkinkan lahirnya berbagai efek signifikasi. Berdasarkan dua fokus ini, tampak bahwa karya sastra sebelumnya banyak berperan dalam sebuah penciptaan
(Suwardi Endraswara, 2003: 133; Culler dalam Jabrohim dan Ari Wulandari, 2001: 113).

Beberapa pendapat di atas, jelas menegaskan bahwa prinsip intertekstualitas menekankan terjadinya proses keberlangsungan pemaknaan secara luas antara teks-teks yang kemudian dan teks-teks yang terdahulu. Keberlangsungan pemaknaan menandai hubungan antarteks baik yang bersifat hubungan persamaan maupun pertentangan. Karya sastra yang melatarbelakangi penciptaan karya sastra sesudahnya disebut sebagai karya hipogram, sedangkan karya yang diciptakan berdasarkan hipogram disebut karya transformasi.

\section{METODOLOGI PENELITIAN}

Metode penelitian merupakan cara ilmiah untuk mendapatkan data dengan tujuan dan kegunaan tertentu. Adapun tujuan dari penelitian adalah bersifat penemuan, pembuktian, dan pengembangan (Sugiyono, 2012: 2). Penelitian novel "Siti Nurbaya karya Marah Rusli dan Laila Majnun Karya Syaikh Nizami" menggunakan metode kualitatif, yaitu penelitian yang bersifat deskriptif. Penelitian kualitatif merupakan penelitian yang cenderung menggunakan analisis.

Data yang digunakan berupa data kualitatif yang tidak terdiri atas angka-angka sehingga data yang dihasilkan berupa data deskriptif. Data deskriptif adalah data yang berupa kata-kata tertulis atau lisan dari orang-orang dan perilaku yang dapat diamati (Moleong, 2001:3). Oleh karena itu, dalam penelitian ini penulis tidak menggunakan angka-angka atau perhitungan, melainkan pemahaman, data analisis, dan diuraikan dalam bentuk kata-kata atau kalimat. Sehingga laporan penelitian berisi kutipankutipan data untuk memberi gambaran penelitian tersebut. Endaswara (2003:5) mengungkapkan bahwa penilitian yang paling cocok bagi fenomena sastra adalah penelitian kualitatif. Hal ini perlu dipahami, karena karya sastra adalah dunia kata dan 
simbol yang penuh makna. Teknik pengumpulan data pada novel dengan teknik baca dan catat.

Pendekatan penelitian ini menggunakan kajian intertekstualitas yaitu membandingkan dua buah teks yang diduga memiliki keterkaitan dan pendekatan intertekstual ini untuk menemukan hipogram dan transformasi dalam novel Siti Nurbaya dan Laila Majnun.

\section{HASIL DAN PEMBAHASAN}

Deskripsi Novel yang dibandingkan

Sinopsis Novel Laila Majnun Karya

\section{Sheikh Nizami}

"Layla-Majnun" Qays bin Al Mulawwah merupakan tokoh sentral dalam novel ini, bukanlah tokoh fiktif, ia memang benarbenar hidup pada masa Bani Umayyah, sepeninggal Qays kisah cinta Qays dengan Layla tersebar dari mulut ke mulut dalam bentuk syair dalam berbagai versi, kemudian Dalam versi Nizami Qays dan Layla samasama jatuh cinta ketika keduanya bertemu disekolah tempat mereka menuntut ilmu bersama kisah ini diawali oleh perasaan cinta yang menggila dari seorang pemuda tampan yang terkenal dikawasan bani Amir Jazirah Arab, bernama Qays. Ia mencintai Layla dan Laila pun sama, mereka menjalin kisah cinta secara sembunyi karena pada waktu itu mereka belum saatnya untuk memadu cinta tapi seiring berjalannya waktu kisah mereka tidak bisa disembunyikan lagi, semua orang pada tau bahkan keluarganya yang pada akhirnya mereka tidak bisa bertemu lagi. Dalam perjalanan, Layla dinikahkan secara paksa oleh ayahnya dengan lelaki yang bernama Ibnu Salam. Namun dia tidak bisa menjamah kegadisan Layla, yang selalu setia kepada Qais hingga akhir hayatnya, Lama tidak bertemu qais tidak kuat menahan rasa cinta yang seperti bara, iapun seperti gila, bertingkah dan berpenampilan aneh hingga orang-orang memanggilnya majnun. Dari rasa kecintaannya yang mendalam majnun mendapat berita bahwa Layla menikah dan kabar buruk lain yang lain berita ayahnya yang meninggal, kemudian tidak lama setelah itu sang Ibu tercintapun mengikuti jejak ayahnya. Inilah puncak kesedihan, hingga suatu peristiwa yang membuat hati terluka ketika majnun mendengar sang kekasih meninggal dunia lalu majnun mengunjungi makam Layla Lalu menangis dan menjerit. Ia memeluk kuburan Layla hingga Majnu menghembuskan nafas terakhirnya diatas kuburan Layla.Syaikh Nizami (1141-1209) pada tahun 1188 menghimpun dan menuliskah kisah tersebut.

\section{Sinopsis Novel Siti Nurbaya Karya Marah Rusli}

Ibunya meninggal saat Siti Nurbaya masih kanak-kanak, Maka bisa dikatakan itulah titik awal penderitaan hidupnya. Sejak saat itu hingga dewasa dan mengerti cinta ia hanya hidup bersama Baginda Sulaiman ayah yang sangat disayanginya. Ayahnya adalah seoranga pedagang yang terkemuka di Kota Padang. Sebagian modal usahanya merupakan uang pinjaman dari seorang rentenir bernama Datuk Maringgi.

Pada mulanya usaha pedagangan baginda Sulaiman mendapat kemajuan pesat, hal itu tidak dikehendaki leh rentenir seperti Datuk Maringgi. Maka untuk melampiaskan keserakahannya Datuk Maringgi menyuruh kaki tangannya membakar semua kios milik Baginda Sulaiman dengan demikian hancurlah usaha Baginda Sulaiman. Ia jatuh miskin dan tak sanggup membayar utangutangnya pada Datuk Maringgih dan inilah kesempatan yang dinanti-nantikannya Datuk Maringgi mendesak Baginda Sulaiman yang sudah tak berdaya agar melunasi semua hutang-hutangnya boleh hutang tersebut dianggap lunas asalkan Baginda Sulaiman mau menyerahkan Siti Nurbaya putrinya kepada Datuk Maringgi.

Menghadapi kenyataan seperti itu Baginda Sulaiman yang memang sudah tak sanggup lagi membayar hutang-hutangnya tidak menemukan pilihan lain selain yang ditawarkan oleh Datuk Maringgi.

Siti Nurbaya menangis menghadapi kenyataan bahwa dirinya yang cantik dan muda berlia harus menikah dengan Datuk 
Maringgi yang sudah tua bangka dan berkulit kasar seperti katak. Lebih sedih lagi ketikaIa teringat Samsul Bahri kekasihnya yang sedang sekolah di Stovia Jakarta. Sungguh berat memang namun demi keselamatan dan kebahagiaan Ayahandanya ia mau mengorbankan kehormatan dirinya dengan Datuk Maringgi.

Samsul Bahri yang ada di Jakarta mengetahui peristiwa yang terjadi di desanya, Terlebih karena Siti Nurbaya mengirimkan surat yang menceritakan tentang nasib yang dialami keluarganya. Pada suatu hari ketika Samsul Bahri dalam liburan kembali ke Padang, Ia dapat bertemu empat mata dengan Siti Nurbaya yang telah resmi menjadi istri Datuk Maringgi. Pertemuan itu diketahui oleh Datuk Maringgi sehingga terjadi keributan. Teriakan Siti Nurbaya terdengar oleh ayahnya yang tengah terbaring karena sakit keras. Baginda Sulaiman berusaha bangkit tetapi akhirnya jatuh tersungkur dan menghembuskan nafas terakhir.

Mendengar itu Ayah Samsul Bahri yaitu Sultan Mahmud Syah yang kebetulan menjadi penghulu Kota Padang, malu atas perbuatan anaknya sehingga Samsul Bahri harus kembali ke Jakarta dan Ia berjanji untuk tidak kembali lagi kepada keluarganya di Padang. Datuk Maringgi juga tidak tinggal diam karena Siti Nurbaya di usirnya.

Tak lama kemuadian Siti Nurbaya meninggal dunia karena memakan lemang beracun yang sengaja diberikan oleh kaki tangan Datuk Maringgih. Kematian Siti Nurbaya itu terdengar oleh Samsul Bahri sehingga dia menjadi putus asa dan mencoba melakukan bunuh diriakan tetapi mujurlah karena ia tak meninggal sejak saat itu samsul bahri tidak meneruskan sekolahnya dan memasuki dinas militer.

Sepuluh Tahun kemudian dikisahkan di Kota Padang sering terjadi huru-hara dan tindakan kejahatan akibat ulah Datuk Maringgi dan orang-orangnya Samsul bahri yang telah berpangkat Letnan dikirim un tuk melakukan pengamanan. Samsul Bahri yang mengubah namanya menjadi Letnan Mas segera menyerbu kota padang. Ketika bertemu dengan Datuk Maringgi dalam suatu keributan tanpa berpikir panjang lagi Samsul Bahri menembaknya Datuk Maringgi jatuh tersungkur, Namun sebelum tewas Ia sempat membacok kepala Samsul Bahri dengan parangnya.

Samsul Bahri alias Letnan Mas Segera dilarikan kerumah sakit pada saatsaat terakhir menjelang ajalnya, Ia meminta dipertemukan dengan Ayahandanya. Tetapi ajal lebih dulu merenggut sebelum Samsul Bahri sempat bertemu dengan orang tuanya.

\section{Persamaan novel layla majnun karya Syeikh Hakim An-Nizami dengan novel "Siti Nurbaya" karya Marah Rusli \\ Persamaan Penggambaran tokoh}

Teks Sastra Novel Laila Majnun

Teks Sastra Siti Nurbaya

Diantara anak-anak dari berbagai kabilah, terlihat seorang gadis cantik berusia belasan tahun. Wajahnya anggun mempesona, lembut sikapnya, dan penampilannya amat bersahaja. Gadis itu bersinar cerah seperti matahari pagi, tubuhnya laksana pohon cemara, dan bola matanya hitam laksana mata rusa. Rambutnya hitam, tebal bergelombang. Gadis yang menjadi buah bibir dan penghias mimpi itu bernama layla

"Anak ini pun seorang gadis, yang dapat dikatakan tidak bercacat,karena bukan rupanya saja yang cantik tetapi kelakuan dan adatnya, tertibdansopannya,sertakebaikan hatinya,tiadalah kurang daripada kecantikan parasnya.."

Analisis:

Kutipan teks sastra di atas menunjukan adanya persamaan pada penggambaran tokoh dari dimensi fisik kedua tokoh yakni laila dalam novel "Laila Majnun" karya syeikh Nizami dan Tokoh Nurbaya dalam Novel "Siti Nurbaya" karya Marah Rusli digambarkan sebagai sosok gadis cantik dan baik budi pekertinya banyak orang yang tergila-gila pada kecantikan keduanaya dapat disimpulkan bahwa kedua tokoh wanita tersebut berwatak protagonist. 


\section{Persamaan Sudut Pandang}

Teks Sastra Novel Laila Majnun

Teks Sastra Novel Siti Nurbaya

"Lihat dia-dia adalah majnun si gila."

"Bila dia mati minta dikuburkan antara ibunya dan Nurbaya."

Analisis:

Kutipan teks sastra diatas menunjukkan adanya persamaan yang terletak pada struktur sudut pandangnya yakni mengunakan sudut pandang orang ketiga di mana penggarang memposisiskan dirinya pada posisi pencerita yang mengetahui banyak hal tentang isi cerita serta ditunjukkan adanya pengunaan kata ganti orang ketiga yakni "Dia" atau penyebutan nama orang di dalamnya.

\section{Persamaan tokoh wanita menikah dengan lelaki yang tak dicintainya}

Teks Sastra Novel Laila Majnun

Teks Sastra Novel Siti Nurbaya

"Pernikahan itu berlangsung cepat orang tua laila merasa lega karena akhirnya semua cobaan berat yang mareka alami akan berakhir."

"Tatkala ayahku akan dibawa kedalam penjara,sebagai penjahat besar,gelaplah mataku dan hilanglah pikiranku, dan dengan tiada yang kuketahui keluarlah aku dan berteriak "jangan penjarakan ayahku! biarkan aku jadi istri datuk maringgih.”

Analisis:

Kutipan teks sastra diatas menunjukkan adanya persamaan yakni tokoh wanita sama-sama menikah dengan lelaki yang tak dicintainya pada tokoh Laila dalam novel "Laila Majnun" menikah dengan Ibn Salam seorang bangsawan yang kaya dan berkuasa sedangkan tokoh Nurbaya dalam novel 'Siti Nurbaya' menikah dengan Datuk Maringgih seoran Lintah darat yang licik, pelit serta bengis.

\section{Persamaan tokoh dimatikan oleh} penggarang

Teks Sastra dalam Novel Laila Majnun

Teks Sastra dalam Novel siti Nurbaya
"Pada saat hari peringatan kematian layla ,teman dansanak keluarga layla menyambanggi kuburan tersebut dan mareka menemukan tubuh terbaring di atas makam tubuh iyu adalah majnun, majnun kemudian dikubur disamping laila."

"Jika tiba waktunya tolong kuburkan aku disamping kuburan nurbaya"

Analisis:

Kutipan Teks Sastra diatas menunjukkan adanya persamaan yakni dari segi tokoh dimatikan oleh penggarang dengan kata lain tokoh-tokoh tersebut meninggal dunia serta kuburan mareka pun terletak disamping kuburan kasih tak sampainya

\section{Perbedaan novel "Laila Majnun" karya Syeikh Nizami dengan Novel Siti Nurbaya karya Marah Rusli}

Selain adanya beberapa persamaan adapula perbedaan antara lain:

\section{Perbedaan Gaya Bahasa}

Teks Sastra dalamNovel Laila Majnun

Teks Sastra dalam novel Siti Nurbaya

"wajahnya seperti nyalanya lentera"(Layla Majnun 2009 : 22)

"bunga melati menyampaikan pesan"(Layla Majnun 2009 : 66)

Padang panjang dilingkar bukit

Bukit dilingkar kayu jati

Kasih sayang bukan sedikit

Dari mulut sampai ke hati

Analisis:

Kutipan diatas menunjukka bahwa adanya perbedaan pada struktur gaya bahasa bilamana sastra timur tengah memang khas dengan penggunaan bahasa kiasan, seperti beberapa kutipan yang telah saya paparkan di atas• Majas simile."wajahnya seperti nyalanya lentera"(LaylaMajnun22)

Disebut majas simile karena membandingkan sesuatu sama dengan yang lainya . Perbandingan tersebut dinyatakan secara eksplisit dengan menggunakan seprti, 'bunga melati menyampaikan pesan" Majnun 2009:66) Disebut personifikasi karena menunjukan kiasan untuk memperlakukan 
benda-benda mati seolah-olah seperti mempunyai sifat-sifat yang ada pada manusia, disini kelopak mawar seperti manusia yang bisa hidup terlantar dan bunga melati seperti manusia bisa menyampaikan pesan. sedangkan dalam novel siti nurbaya banyak ditulis dalam bahasa baku dan termasuk teknik pecitraan tradisional seperti berbagai pantun serta mengunakan bahasa melayu,.Pantun digunakan oleh Nurbaya dan Samsul untuk menjelaskan perasaan mereka,

\section{Perbedaan Latar Sosial}

Teks Sastra dalam Novel Laila Majnun

Teks Sastra dalam Novel Siti Nurbaya

"Angin berhemnbus membawa kisah asmara padakeluarga sigadis kabar itu bagai arang hitam yang membuat bani qhatibiah tersinggung harga diri mareka ternoda bukankah ada pepatah yang mengatakan lebih baik kehilangan nyawa dari pada menanggung malu."

"Sebenarnya pikirku sekali-kali tidak setuju dengan adat berkawin banyak karena terlebih banyak kejahatanya daripada kebaikannya." Analisis:

Kutipan diatas menunjukan adanya perbedaan dari segi latar sosialnya sosialnya dimana pada teks sastra novel Laila Majnun terpapar jelas dibagian awal cerita pada saat qays dan laila ketahuan menjalin kasih, ayah laila merasa terhina menanggung malu mungkin social di arab seperti itu mareka lebih baik kehilangan nyawa daripada harga dirinya terinjak-injak sehingga laila tidak diperbolehkan bertemu kawan-kawanya terutama pada qays sedangkan pada pada Novel Siti Nurbaya terpapar ketidak setujuan sultan mahmud dan Ahmad maula pada poligini-yang dalam islam dibatasi hanya 4 istri saja - disebabkan kondisi minangkabau pada masa itu oleh kaum bangsawan poligini dijadikan alat untuk mencari keuntunggan materi sebab dalam adat minangkabau ,calon istrilah yang membeli seorang laki-laki selain itu adat minangkabau ,seorang anak bukan tanggung jawab ayahnya melainkan mamaknya.

\section{Perbedaan dari segi gaya berpakaian}

Teks Sastra Novel Laila Majnun

Teks Sastra Novel Siti Nurbaya

"Untuk Menghormati kenanganya aku memakai jubah berwarna biru gelap seperti sekuntum bunga violet."

"Pakaian gadis ini pun sebagai pakaian anak belanda rambutnya hitam dan tebal diikatnya dengan benang sutra ,gaunya terbuat dari kain batis yang berkembang merah jambu."

Analisis:

Kutipan teks sastra diatas menunjukkan adanya perbedaan yang ditinjau dari segi gaya berpakaian bilamana pakaian yang digunakan tokoh laila dalam novel "Laila Majnun" adalah baju panjang (jubah) atau yang sering disebut Abaya oleh masyarakat timur tengah yang digunakan dengan disertai penutup kepala (kerudung) sedangkan pakaian yang dikenakan tokoh nurbaya dalam novel "Siti Nurbaya" adalah pakaian anak belanda atau biasa disebut (baju nona-nona)

\section{Perbedaan dari segi penyebab kematian}

Teks Sastra dalam Novel Laila Majnun

Teks sastra dalam Novel Siti Nurbaya

"Akhirnya batuk kronis yang dideritanya menyerangnya dengan hebat."

"Pada keesokan harinya nyatalah kepadanya bahwa nurbaya termakan racun itulah yang menyebabkan mautnya."

Analisis:

Kutipan teks sastra diatas menunjukkan adanya perbedaan dari segi penyebab kematian kedua tokoh tersebut bilamana tokoh Laila dalam novel "Laila Majnun" meninggal akibat sakit yang dideritanya (batuk kronis) sedangkan tokoh Nurbaya dalam Novel "Siti Nurbaya" meninggal akibat memakan lemang yang telah dibubuhi Racun oleh anak buah datuk maringgih.

\section{Hipogram}

Novel Siti Nurbaya karya Marah Rusli merupakan hipogram untuk novel Laila Majnun karya Syaikh Nizam. Hal itu terbukti karena adanya persamaan ide dan peristiwa- 
peristiwa yamg terjadi dalam novel Laila Majnun yang sudah lebih dulu diekspresikan Marah Rusli dalam novelnya yang berjudul Siti Nurbaya, kemudian di transformasikan oleh Syaikh Nizam pada novelnya yang berjudul Laila Majnun.

\section{SIMPULAN}

Kedua cerita Novel LaIla Majnun karya Syaikh Nizami dan Novel Siti Nurbaya Cinta karya Marah Rusli di atas yakni memiliki unsur tema yang hampir sama yaitu tentang perjuangan cinta sejati sepasang kekasih yang mengalami cobaan atau hambatan namun menyatu dalam sebuah keabadian mengunakan sudut pandang yang sama yakni sudut pandang orang ketiga dan lain-lain. Selain persamaan ada juga perbedaan yakni terletak pada struktur gaya bahasa, latar sosial dan lain-lain.

Novel Siti Nurbaya karya Marah Rusli merupakan hipogram untuk novel Laila Majnun karya Syaikh Nizam. Hal itu terbukti karena adanya persamaan ide dan peristiwaperistiwa yamg terjadi dalam novel Laila Majnun yang sudah lebih dulu diekspresikan Marah Rusli dalam novelnya yang berjudul Siti Nurbaya, kemudian di transformasikan oleh Syaikh Nizam pada novelnya yang berjudul Laila Majnun.

\section{DAFTAR PUSTAKA}

Nizami, Syaikh. 2003. Laila Majnun. Yogyakarta: Navila.

Rusli, Marah. 2011. Siti Nurbaya. Jakarta Timur : Balaipustaka.

Rejo, Uman. 2010. "Tokoh Utama Perempuan dalam Novel Pengakuan Pariyem Karya Linus Suryadi AG dan Novel Berkisar Merah Karya Ahmad Tohari Telaah Intertekstual." Universitas Negeri Surabaya. Jurnal Ilmu Pendidikan, (Online) Dalam (http://www.surabaya.ac.id.).

Diakses pada tanggal 06 Juni 2018).

Restu, Kurniawan. 2010. "Persamaan dan Perbedaan Novel Laskar Pelangi karya Andrea Hirata dengan Novel Ranah 3 Warna Karya A. Fuadi." Universitas Ahmad Dahlan Yogyakarta. Jurnal Ilmu Pendidikan. (Online). Dalam (http://www.Yogyakarta .ac.id).

(Diakses pada tanggal 06 Juni 2018). 